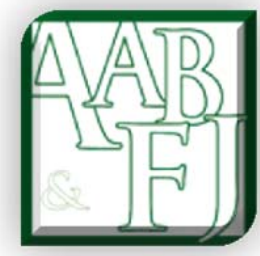

\title{
Editorial Volume 7 Issue 2
}

Ron Perrin ${ }^{1}$, Ciorstan Smark² \& Greg Laing ${ }^{3}$

The articles published in this issue of AABFJ are drawn from accounting, economics and finance discipline areas. Juliarto, Tower, Van der Zahn and Rusmin (2013) investigate the extent and the determinants of tunnelling behaviour in five ASEAN countries and find a positive association between managerial ownership and the extent of tunnelling. Wasiuzzaman and Arumugam (2013) examine the determinants of the level of investment in net operating working capital by firms in Malaysia and finds that in times of economic expansion, younger and smaller firms with less tangible assets, low leverage, high immediate sales growth, high operating cash flows, less volatile revenues and low levels of asymmetric information are likely to have the highest investments in operating working capital. Bhuiyan, Jamal Roudaki \& Murray Clark (2013) investigate the effect of better compliance with corporate governance regulation on managerial accruals (discretionary accruals) in New Zealand listed companies.

Zhang, Cheng and Charles Harvie (2013) examine the contribution and significance of firm size to the establishment, operation and success of business collaboration. Results from both the qualitative case study and quantitative study in Australia and China show that size plays a significant positive role in the formation and performance of business collaboration. Firms prefer collaborating with larger partners. Bigger firms are more likely to achieve success collaborations. However, size difference plays a negative role in business collaboration.

Wei, Gerace and Frino (2013) study the estimation of intraday time-varying volume synchronised probability of informed trading (VPIN), a proxy for levels of informed trading and flow toxicity, followed by intraday analysis on its impact of the behaviour of intraday trading in a limit order book (LOB) market.

\footnotetext{
${ }^{1}$ University of Wollongong, Australia

${ }^{2}$ University of Wollongong, Australia

${ }^{3}$ University of the Sunshine Coast, Australia GLaing@usc.edu.au
} 


\section{References}

Bhuiyan, Md. Borhan Uddin; Roudaki, Jamal; and Clark, Murray, 2013, Corporate Governance Compliance and Discretionary Accruals: New Zealand Evidence, Australasian Accounting Business and Finance Journal, 7(2), 87-110.

Available at:http://ro.uow.edu.au/cgi/siteview.cgi/aabfj/vol7/iss2/7

Hoque, Ariful and Krishnamurti, Chandrasekhar, 2013, A Proposed Solution for the Chicken-Egg Dilemma in Pricing Currency Options, Australasian Accounting Business and Finance Journal, 7(2), 71-86.

Available at:http://ro.uow.edu.au/cgi/cview.cgi/aabfj/vol7/iss2/6

Juliarto, Agung; Tower, Greg; Van der Zahn, Mitchell; and Rusmin, Rusmin, 2013, Managerial Ownership Influencing Tunnelling Behaviour, Australasian Accounting Business and Finance Journal, 7(2), 25-32.

Available at:http://ro.uow.edu.au/aabfj/vol7/iss2/3

Wasiuzzaman, Shaista and Arumugam, Veeri Chettiar, 2013, Determinants of Working Capital Investment: A Study of Malaysian PublicListed Firms, Australasian Accounting Business and Finance Journal, 7(2), 49-70.

Available at:http://ro.uow.edu.au/cgi/cview.cgi/aabfj/vol7/iss2/5

Wei, Wang Chun; Gerace, Dionigi; and Frino, Alex, 2013, Informed Trading, Flow Toxicity and the Impact on Intraday Trading Factors, Australasian Accounting Business and Finance Journal, 7(2), 3-24.

Available at:http://ro.uow.edu.au/cgi/cview.cgi/aabfj/vol7/iss2/2

Zhang, Yu; Cheng, Zhiming; and Harvie, Charles, 2013, The Roles of Size and Size Difference in Australian and Chinese Inter-firm Collaborations, Australasian Accounting Business and Finance Journal, 7(2), 33-48.

Available at:http://ro.uow.edu.au/cgi/cview.cgi/aabfj/vol7/iss2/4 